\title{
MOTIVATION RELATIONSHIP WITH CLEAN AND HEALTHY LIVING BEHAVIORS NURSING STUDENTS
}

\author{
Risnah$^{1}$, Meilinda Nur Khafifa ${ }^{2}$, Nur Hidayah ${ }^{3}$, Muhammad Irwan ${ }^{4}$ \\ Email : risnah@uin-alauddin.ac.id \\ 1,2,3 Nursing Department, Faculty of Medicine and Health Sciences Universitas IslamNegeri Alauddin Makassar \\ ${ }^{4}$ Nursing Department, Health Faculty, Universitas Sulawesi Barat
}

\section{ABSTRACT}

The campus environment is a place for students to study and their mindset should be able to apply PHBS in the campus environment and be able to apply it in everyday life. The purpose of this study was to determine the relationship between motivation and clean and healthy life behavior (phbs) in nursing students. This research design using quantitative with cross sectional approach. The sample in this study were all nursing students in semester 2 with a total sample of 68 respondents. The results of the study using the Chi-square test with a significance level of 0.05 , the results obtained were $P=0.009$, because the $p$ value $<0.05$, the hypothesis was accepted that there was a significant relationship between motivation and clean and healthy living behavior (PHBS) of nursing students. However, more than $20 \%$ of cells that have an expected count of less than 5 , which means that they do not have requirements for the chi-square test, it can be seen that the Fisher's Exact Test value is 0.054, which means that the p value <0.05. So it can be concluded in this study that there is a significant relationship between motivation and PHBS clinically, but it does not have a statistically significant relationship.

\section{ABSTRAK}

Lingkungan kampus merupakan tempat mahasiswa untuk menuntut ilmu dan pola pikirnya harus mampu menerapkan PHBS di lingkungan kampus dan mampu menerapkannya dalam kehidupan sehari-hari. Tujuan penelitian ini adalah untuk mengetahui hubungan motivasi dengan perilaku hidup bersih dan sehat (PHBS) pada mahasiswa keperawatan. Desain penelitian ini menggunakan kuantitatif dengan pendekatan cross sectional. Sampel dalam penelitian ini adalah seluruh mahasiswa keperawatan semester 2 dengan jumlah sampel 68 responden. Hasil penelitian menggunakan uji Chi-Square dengan taraf signifikan 0,05 diperoleh hasil $\mathrm{P}=0,009$, karena Pvalue $<0,05$ maka hipotesis diterima bahwa ada hubungan yang signifikan antara motivasi dengan hidup bersih dan sehat perilaku (PHBS) pada mahasiswa keperawatan. Namun lebih dari $20 \%$ sel memiliki ekspektasi jumlah kurang dari 5 yang artinya tidak memenuhi syarat uji chi-square, maka nilai Fisher's Exact Test adalah 0,054 yang berarti nilai $p<0,05$. Sehingga dapat disimpulkan dalam penelitian ini bahwa ada hubungan yang signifikan antara motivasi dengan PHBS secara klinis, namun tidak memiliki hubungan yang signifikan secara statistik.

\section{ARTICLE INFO}

Keywords:

Motivation; Clean and Healthy Life Behavior;

Nursing Students

\section{Preliminary}

Health is the key to well-being. Healthy individuals can play an active role and contribute to the development of religion, nation and State. Health problems that have become a hot issue in society in 2017 are closely related to clean and healthy living habits, the lack of application of phbs in daily activities which ultimately results in the emergence of various infectious and noncommunicable diseases. Although the application looks simple, there are still many students who ignore phbs in their daily lives. Diseases that arise due to low PHBS are diarrhea, worms, skin disease, toothache, malnutrition and so on which ultimately results in low health status in Indonesia and low quality of life for human resources.(Ministry of Health, 2018) According to (WHO) around 2.2 million people, mainly children, die each year in developing countries from various diseases that result from a lack of safe clean drinking water, poor sanitation and hygiene. In addition, there is also evidence that adequate sanitation, availability of clean water, sanitation systems and hygiene education can reduce mortality from diarrhea by up to $65 \%$ and other diseases by $26 \%$.(Astuti, 2013) 
Based on the results of Riskesdas 2018, there are 3 GERMAS points that are in the problematic PHBS indicator and have not shown an increase compared to Riskesdas 2013.The first indicator is the prevalence of smoking in the population aged 10-18 years of 9.1\%, an increase compared to Riskesdas in 2013 which was $7,2 \%$. The second indicator is the inadequate level of physical activity of the population aged 10 years and over, with a national average of $33.5 \%$, with the West Sumatra region average of 39\%. The third indicator is the low proportion of fruit and vegetable consumption among people aged 25 years and over with a national average of $95.5 \%$, with West Sumatra at 98\%.(Ministry of Health, 2019)

Clean and healthy living behavior (PHBS) is a set of behaviors carried out with awareness as a result of learning which makes it a person who can help himself in the sphere of health and plays an active role in improving health in the community.(Ministry of Health, 2011). Clean healthy living behavior is an effort to provide experiences in learning and create conditions for individuals, families, groups and communities, through communication, providing information as well as education in increasing knowledge about behavioral attitudes through advocacy (leadership) approaches, social support (mentoring), and also empowerman (community empowerment), as an effort to help people overcome their own problems in the surrounding environment, so that they are able to practice a healthy way of life, in order to maintain health, maintain health and improve health.(Novita, 2017)

Growing a clean and healthy lifestyle is actually not difficult, but one must have the desire to start it. Every student is able to adopt a clean and healthy lifestyle as well as make this clean healthy behavior a habit that must be done. When a good habit has been instilled in the individual, it will not be difficult to do it, because something that is done in a habit will be very easy to do. So it is hoped that students will be able to instill the principle that health is a need that must be met so that we are motivated to excel and do it(Novita, 2017). The purpose of this study was to determine the relationship between motivation and clean and healthy living behavior (PHBS) among nursing students.

\section{Research Methods}

Deep method This study used a cross sectional approach. This research was conducted in the Department of Nursing Semester 2 Faculty of Medicine and Health Sciences UIN Alauddin Makassar online using a questionnaire in the form of google form. The study was conducted on 18-22 May 2020. The population in this study were the second semester nursing students of the Faculty of Medicine and Health Sciences, UIN Alauddin Makassar. In this study, sampling was carried out using a total sampling technique, namely the total population of 68 students. The instrument used was a questionnaire, and data processing through the stages of editing, coding, tabulating, as well as univariate and bivariate analysis using the ChiSquare test and Fisher's Exact Test.

\section{Research Results and Discussion}

This research is about the relationship between motivation and clean and healthy lifestyle (PHBS) second semester nursing students which was conducted on 18-22 May 2020.

Table 1.1

Frequency distribution based on age, gender and ethnicity in second semester nursing students Uin Alauddin Makassar

\begin{tabular}{ccc}
\hline Variable & Frequency & Percent (\%) \\
\hline Age & & 45.6 \\
17-18 Years & 31 & 54.4 \\
19-20 Years & 37 & \\
\hline Gender & & 10.3 \\
Male & 7 & 89.7 \\
\hline
\end{tabular}




\begin{tabular}{ccc}
\hline Tribe & & \\
\hline Makassar & 19 & 27.9 \\
Bugis & 24 & 35.3 \\
Bugis Makassar & 7 & 10.3 \\
Bima & 8 & 11.8 \\
Others & 10 & 14.7 \\
\hline total & $\mathbf{6 8}$ & $\mathbf{1 0 0}$
\end{tabular}

\section{Source: Dataprimer 2020}

Table 1.1 shows that respondents aged 17-18 years were $31(45.6 \%)$ and respondents aged 19-20 years were 37 (54.4\%). Frequency The sex of male respondents was $7(10.3 \%)$ and most of them were female, amounting to $61(89.7 \%)$. The ethnic frequency from Makassar was 19 respondents (27.9\%), from the Bugis ethnic group as many as 24 respondents (35.3\%), from the Bugis Makassar tribe as many as 7 respondents (10.3\%), from the Bima tribe as many as 8 respondents $(11,8 \%)$ and from other tribes namely Mandar, Batak, Muna, Javanese, Sasak, Ternate, Sasambo, Ambon, and Tae as many as 10 respondents $(14.7 \%)$.

Table 1.2

Respondent Characteristics Crostabulation based on motivation with clean and healthy life behavior (PHBS) nursing students

\begin{tabular}{cccc}
\hline \multirow{2}{*}{ Variable } & \multicolumn{2}{c}{ Motivation } & \multirow{2}{*}{ Total } \\
\cline { 2 - 3 } & Low & High & \\
\hline Age & & & 31 \\
17-18 Years & 0 & 34 & 37 \\
19-20 Years & 3 & & \\
\hline Gender & & 7 & 7 \\
Male & 0 & 58 & 61 \\
Women & 3 & & 19 \\
Tribe & & 19 & 24 \\
Makassar & 0 & 24 & 7 \\
Bugis & 0 & 6 & 8 \\
Bugis Makassar & 1 & 7 & 10 \\
Bima & 1 & 9 & $\mathbf{6 8}$ \\
Others & 1 & $\mathbf{6 5}$ & \\
\hline total & $\mathbf{3}$ & & \\
\hline
\end{tabular}

Source: Dataprimer 2020

Table 1.2 shows that respondents aged 17-18 years do not have low motivation, and those who have high motivation are 31 respondents, respondents aged 19-20 years with low motivation are 3 respondents and respondents with high motivation are 34 respondents. Frequency The gender of the respondent, none of which has low motivation and 7 with high motivation, 3 respondents with low motivation and 58 respondents with high motivation. There is no ethnic frequency from Makassar with low motivation and as many as 15 respondents with high motivation, none of the Bugis ethnic groups have low motivation and as many as 24 respondents with high motivation, 
Table 1.3

Respondent Characteristics Crostabulation based on the clean and healthy lifestyle (PHBS) of nursing students

\begin{tabular}{cccc}
\hline \multirow{2}{*}{ Variable } & \multicolumn{2}{c}{ PHBS } & \multirow{2}{*}{ Total } \\
\cline { 2 - 3 } & Not good & Well & \\
\hline Age & 3 & 28 & 31 \\
17-18 Years & 7 & 30 & 37 \\
\hline 19-20 Years & & & \\
\hline Mender & 2 & 5 & 7 \\
Women & 8 & 53 & 61 \\
\hline Tribe & & & 19 \\
Makassar & 3 & 16 & 24 \\
Bugis & 5 & 19 & 7 \\
Bugis Makassar & 1 & 6 & 8 \\
Bima & 1 & 7 & 10 \\
Others & 0 & 10 & $\mathbf{6 8}$ \\
\hline Total & $\mathbf{1 0}$ & $\mathbf{5 8}$ & \\
\hline
\end{tabular}

Source: Primary data 2020

Table 1.3 shows that there were 3 respondents aged 17-18 years who had a bad PHBS, and 28 respondents who had a good PHBS, 7 respondents aged 19-20 years who had a bad PHBS and 30 respondents who had a good PHBS. . Frequency The sex of male respondents who had a bad PHBS was 2 respondents and 5 respondents had a good PHBS, 8 respondents had a bad PHBS, and 53 respondents had a good PHBS. The frequency of ethnic groups from Makassar who had a bad PHBS was 3 respondents and as many as 16 respondents had a good PHBS, 5 respondents from the Bugis tribe who had a bad PHBS and as many as 19 respondents had a good PHBS,

\section{Univariate Analysis}

Table 1.4

Frequency distribution based on motivation with clean and healthy life behavior (PHBS) nursing students

\begin{tabular}{ccc}
\hline Motivation & F & \% \\
\hline High & 65 & 95.6 \\
Low & 3 & 4,4 \\
\hline Total & $\mathbf{6 8}$ & $\mathbf{1 0 0}$ \\
\hline
\end{tabular}

\section{Source: Primary Data 2020}

Based on table 1.4 above shows that there are 3 respondents or as many as $4.4 \%$ have a low level of motivation and there are 65 respondents or as many as $95.6 \%$ have a high level of motivation.

Table 1.5

The frequency distribution is based on the clean and healthy lifestyle (PHBS) of nursing students

\begin{tabular}{ccc}
\hline PHBS & F & \% \\
\hline Well & 58 & 85.3 \\
Not good & 10 & 14.7 \\
\hline Total & $\mathbf{6 8}$ & $\mathbf{1 0 0}$
\end{tabular}

Source: Primary Data 2020 
Based on table 1.5, it shows that there were 10 respondents or as many as $14.7 \%$ had poor PHBS and there were 58 respondents or as many as $85.3 \%$ had good PHBS.

Bivariate Analysis

Table 1.6

Cross tabulation between motivation and hygiene and healthy living behavior (PHBS) nursing students

\begin{tabular}{|c|c|c|c|c|c|}
\hline & & \multicolumn{2}{|c|}{ PHBS } & \multirow[t]{2}{*}{ Total } & \multirow[t]{2}{*}{$P$} \\
\hline & & Not good & Well & & \\
\hline \multirow[t]{2}{*}{ Motivation } & Low & 2 & 1 & 3 & \multirow{2}{*}{0.009} \\
\hline & High & 8 & 57 & 65 & \\
\hline \multicolumn{2}{|c|}{ Total } & 10 & 58 & 68 & \\
\hline
\end{tabular}

Source: Primary Data 2020

Based on table 1.6 above, it shows that the results of cross-tabulation between motivation and clean and healthy life behavior (PHBS) of nursing students, using the Chi-Square Test with a significance level of 0.05 obtained the result $P=0.009$, because the p value $<0.05$, the hypothesis is accepted that there is a relationship. There is a significant difference between motivation and clean and healthy life behavior (PHBS) of nursing students. But having more than $20 \%$ of cells that have an expected number of less than 5, which means that these cells do not meet the requirements for the chi-square test, the Fisher's Exact Test value is used, the value is 0.054, which means the $\mathrm{p}$ value $<0.05$ means that $\mathrm{Ha}$ is accepted and $\mathrm{HO}$ is rejected. So it can be concluded that in this study there is a significant relationship between motivation and PHBS clinically.

In this study, it shows that there are 3 respondents or as many as $4.4 \%$, who have low motivation with an age range of 19-20 years as many as 3 respondents, from the female gender as many as 3 respondents and from the Bugis Makassar tribe as many as 1 respondent, 1 respondent from Bima tribe and 1 respondent from other tribes.And there are 65 respondents or as many as $95.6 \%$ have a high level of motivation with an age range of 17-18 years as many as 31 respondents, aged 19-20 years as many as 37 respondents, from the male gender as many as 7 people. Female respondents were 5819 respondents and came from the Makassar Tribe, 24 from the Bugis Tribe, 6 from the Bugis Makassar Tribe, 7 from the Bima Tribe and 9 from the Other Tribe. Then as many as 10 respondents or $14.7 \%$ had less good PHBS with ages 17-18 years as many as 3 respondents, ages 19-20 years as many as 7 respondents, from male gender as many as 2 respondents, female gender as many as 8 respondents and 3 Respondents from the Makassar tribe, 5 respondents from the Bugis tribe, 1 respondent from the Bugis Makassar tribe, and 1 respondent from the Bima tribe. And there are 58 respondents or as many as 85, 3\% have good PHBS with an age range of 17-18 years as many as 28 respondents, aged 19-20 years as many as 30 respondents, from the male gender as many as 5 respondents, 53 respondents from the female and 16 respondents from the Makassar tribe, 19 respondents from the Bugis tribe , 6 respondents from the Bugis Makassar tribe, 7 respondents from the Bima tribe and 10 from other tribes as many as 10 respondents. Based on the results using the Chi Square test with a significant level of 0.05 , the P results were 0.009 , because $p$ value $<0.05$, the hypothesis was accepted that there was a significant relationship between motivation and clean and healthy living behavior (PHBS) of nursing students. There were 53 women respondents and 16 respondents from the Makassar tribe, 19 respondents from the Bugis tribe, 6 respondents from the Bugis Makassar tribe, 7 respondents from the Bima tribe and 10 from other tribes as many as 10 respondents. Based on the results using the Chi Square test with a significant level of 0.05, the $\mathrm{P}$ results were 0.009 , because $\mathrm{p}$ value $<0.05$, the hypothesis was accepted that there was a significant relationship between motivation and clean and healthy living behavior (PHBS) of nursing students. There were 53 women respondents and 16 respondents from the Makassar 
tribe, 19 respondents from the Bugis tribe, 6 respondents from the Bugis Makassar tribe, 7 respondents from the Bima tribe and 10 from other tribes as many as 10 respondents. Based on the results using the Chi Square test with a significant level of 0.05 , the P results were 0.009 , because the $p$ value $<0.05$, the hypothesis was accepted that there was a significant relationship between motivation and clean and healthy living behavior (PHBS) of nursing students.

Before the research was conducted, respondents were selected according to the inclusion criteria set by the researcher, namely students of the second semester of the Faculty of Medicine and Health Sciences UIN Alauddin Makassar. In the implementation of this research, students were given an online questionnaire in the form of a google form about motivation and hygiene and healthy living behavior (PHBS) where the motivation questionnaire contained 10 questions with 7 positive questions and 3 negative questions, then a clean and healthy lifestyle questionnaire (PHBS). ) contains 7 questions with 5 positive questions and 2 negative questions.

Motivation is closely related to clean and healthy living behavior, because motivation is one of the internal factors or encouragement from within a person to take an action or goal to be achieved, including implementing a clean and healthy lifestyle. Clean and healthy living behavior is an effort to provide learning experiences and create conditions for individuals, families, groups as well as communities by means of communicating, providing information and education in increasing knowledge of one's attitudes and behavior in carrying out clean and healthy living behaviors.

\section{Conclusion}

Based on the results of the study, it was found that the characteristics of respondents were based on age, namely the ages of 17-18 years as many as 31 and those between 19-20 years as many as 37 people. The sex of male respondents was 7 people and female respondents were 61 people. There are 19 people from Makassar, 24 from the Bugis tribe, 7 from the Bugis Makassar tribe, 8 from the Bima tribe and from other tribes namely Mandar, Batak, Muna, Javanese, Sasak, Ternate, Sasambo, Ambon, and tae as many as 10 people. Based on the results of research using the Chi-square test with a significance level of 0.05 , the result was $P=0.009$, because the $p$ value $<0.05$, the hypothesis was accepted that there was a significant relationship between motivation and clean and healthy living behavior (PHBS) of nursing students. But having more than $20 \%$ of cells that have an expected count of less than 5 , which means that they do not meet the requirements for the chi-square test, the value of the Fisher's Exact Test is used. refuse. So it can be concluded that in this study there is a significant relationship between motivation and PHBS clinically, but it does not have a statistically significant relationship.For future researchers who want to investigate the relationship between motivation and hygiene and healthy living behavior (PHBS) in nursing students, this research can be the basis and it is hoped that in their research to use a larger sample.

\section{Bibliography}

Andini, B. (2018). The Relationship between Attitudes and Motivation with the Implementation of Clean and Healthy Living Behavior (PHBS) in Families in the Work Area of the Gulai Bancah Community Health Center, Bukittinggi City, 2018. Thesis. Stikes Perintis Padang.

Astuti, Y. et al. (2013). Communication Education and Information (PHBS) Behavior of Clean and Healthy Living Semester V. Vield Lab Module Revision Edition 2. Ministry of Education and Culture, Sebelas Maret University.

Handoko, TH (2008). Personnel and Human Resources Management (2nd ed.). BPFE.

Hidayati, P.. (2019). Clean and Healthy Life Behavior (PHBS) according to the teachings of Islam of grade V MI Maarif Dukuh students. Elementary, Volume $7 \mathrm{~N}$.

Imron, T. (2014). Research Methodology in the Health Sector (Kedu Edition). Sagung Seto.

Ministry of Health, R. (2011). Regulation of the Minister of Health of the Republic of Indonesia Number: 2269 / menkes / per / XI / 2011 Guidelines for the Development of Clean and 
Healthy Behavior (PHBS). RI Ministry of Health.

Ministry of Health, R. (2015). Ministry of Health Strategic Plan 2015-2019 "Decree of the Minister of Health of the Republic of Indonesia Number HK.02.02 / Menkes / 52/2015. RI Ministry of Health.

Ministry of Health, R. (2018). Indonesia Health Profile 2017. Kemenkes RI.

Ministry of Health, R. (2019). National Riskesdas 2018 Report. In Basic Health Research 2018. Kemenkes RI.

Lestari, SNEH \& MS (2016). Description of Clean and Healthy Living Behavior (PHBS) in School for Students of SD Kembangarum 02 West Semarang. Journal of Nursing and Midwifery (JIKK).

Notoatmodjo, S. (2012). Health Promotion \& Health Behavior. Rineka Cipta.

Nursalam. (2008). Concept and Application of Nursing Research Methodology. Thesis Guidelines, Thesis and Nursing Research Instruments. Salemba Medika ...

Sugiyono. (2016). Quantitative Research Methods, Qualitative and R \& D. Alfabeta.

Sunaryo. (2002). Psychology For Nursing. EGC.

Shah, M. (2004). Psychology of Learning. Grafindo Persada.

Thahirah. (2014). The Relationship between Clean and Healthy Living Behavior (PHBS) and Diarrhea in Children in SD Integral Al-Bayan Al-Bayan Foundation, Hidayatullah Islamic Boarding School Makassar. Essay.

Trisna, E. (2015). The Relationship between Clean and Healthy Living Behavior (PHBS) and Diarrhea in Students. Journal of Nursing, Volume XI (ISSN 1907 - 0357).

Widowati, CA (2016). Overview of Clean and Healthy Living Practices of School-Age Street Children in Halfway Houses in Semarang City. In Thesis. Diponegoro University Semarang.

Yulisetyaningrum. (2015). The Relationship between Clean and Healthy Lifestyle (PHBS) Motivation and Open Defecation in Krajan Hamlet, Karangrowo Village, Undaan District, Kudus Regency, 2014. JIKK, Vol 6. 